\title{
The Compatibility of Higher Education Outcomes with the Requirements of the Labour Market in an Interior Design Programme in the Kingdom of Saudi Arabia
}

\author{
Abeer Abdulaziz Al-Awad, Riham Saeed Bazuhair, Rawan Abdullatif Alhojaly, \\ Maram Mohammed Mossawa \\ Department of Interior Design and Furniture, Faculty of Human Sciences and Designs, King Abdulaziz University, Jeddah, KSA \\ Email: aalawad@kau.edu.sa
}

How to cite this paper: Al-Awad, A. A., Bazuhair, R. S., Alhojaly, R. A., \& Mossawa, M. M. (2020). The Compatibility of Higher Education Outcomes with the Requirements of the Labour Market in an Interior Design Programme in the Kingdom of Saudi Arabia. Art and Design Review, 8, 94-113.

https://doi.org/10.4236/adr.2020.82007

Received: March 28, 2020

Accepted: April 20, 2020

Published: April 23, 2020

Copyright $\odot 2020$ by author(s) and Scientific Research Publishing Inc. This work is licensed under the Creative Commons Attribution International License (CC BY 4.0).

http://creativecommons.org/licenses/by/4.0/

\section{(c) (i) Open Access}

\begin{abstract}
This study aimed to explore the compatibility between the outcomes of academic interior design programmes and the needs of the labour market in the Kingdom of Saudi Arabia (KSA) to fill gaps and ensure sustainable development. The study reviewed nineteen academic interior design programmes in different regions, both public and private institutions, and distributed two questionnaires to graduates and employees that assessed seven stages related to the design process and project management. The sample in this study consisted of sixty graduates and nineteen employers in the fields of design or architecture who hire local interior designers. The results indicated that interior design programmes do not fulfill the needs of the market because some regions do not have interior design programmes or the programmes are limited to women, and the image of interior design professions is not clear in some regions due to limited information in the community. Some study plans need to be updated and reviewed based on the latest changes in the labour market. The results also showed that graduates had good knowledge of and skills in the field of interior design, with some shortfalls in the project management skills required in the labour market, such as budget calculations and writing work contracts, timetables, and reports. This limitation may be due to a lack of communication between institutions and the labour market and weak academic guidance for students when choosing elective courses that support these skills. Finally, it is clear that the graduates had good communication, negotiation, persuasion and decision-making skills. The result of this study should help administrators of interior design programmes develop curricula that fulfill the needs of the labour market and help enrolled students increase
\end{abstract}


their knowledge and skills. Finally, the results can inform employers about the necessary training for their interior designers.

\section{Keywords}

Higher Education, Academic Programmes, Interior Designer, Interior Design, Professional Practice, Labour Market

\section{Introduction}

In the past, the Saudi labour market has offered all graduates from higher education institutions many options for work, but the situation has changed in recent years for some specialties (Al-Otaibi, 2007). Presently, the Kingdom of Saudi Arabia (KSA) has a Promising Vision 2030 that has three axes: a vibrant society, a prosperous economy, and an ambitious homeland. With regard to the second axis, the vision focuses specifically on "providing opportunities for all, by building an educational system linked to the needs of the labour market". Therefore, the role of higher education has become important through the development of academic programmes, which need to be compatible with the needs of the labour market.

\subsection{The Role of Higher Education}

Education is linked to economic development issues because of the contemporary trend of examining the degree to which education contributes to solving community problems (Ahmed, 2017). The role of higher education is not limited to making, providing, and transferring knowledge; rather, higher education is one of the driving forces of economic growth (Hendy, 2018; Ahmed, 2017). This means that its role is not limited to providing students with knowledge but extends to how this knowledge is activated in the labour market (Ahmed, 2017). Knowledge is the most prominent element of power and authority in societies around the world and cannot be ignored, as knowledge is the basis for transition from underdevelopment to development. Higher education institutions are social institutions that have been developed by the community to serve the community. Therefore, these institutions must be concerned with developing their programmes to ensure that their outcomes are compatible with the requirements of the labour market and community service, which are the reasons for their establishment (Dagher et al., 2016).

The lack of alignment between learning outcomes and the needs of the labour market may cause an important issue: unemployment, which affects countries socially, economically and politically (Al-Otaibi, 2007). Any deficiency in the outcomes of higher education can have serious consequences, including overcrowding and unemployment. There are many challenges imposed by fast development and globalization that can lead to problems, including the inadequacy of academic specializations for the labour market. Curriculum revision in uni- 
versities occurs after the first cohort of students on the same study plan graduates, and the time needed to measure outcomes after the first cohort graduates range from three to five years.

\subsection{Interior Design Profession}

The Kingdom's 2030 vision enhances the national identity by establishing museums, events, and activities and reviving national heritage sites and constructing suitable housing for residents that meet their needs. In other words, the vision includes very large residential, health, educational and tourism projects; thus, interior design is one of the most vital and important professions in this vision. Al-Zahrani, stated that the interior design sector is one of the largest sectors in the Kingdom, but there is a shortage of Saudi interior designers. There is also a need for specialists in this field, especially with the rapid development and increasing growth in architectural projects and areas that involve interior designers (Al-Zahrani, 2016).

Interior design is considered a modern specialization in education in KSA, where the first department of interior design was established in 1999 at Dar al-Hekma Privet University, according to the official university website (Dar Al-Hekma, 2020). Practising interior design professionally requires academic support that is aligned with current labour market requirements, as higher education interior design programmes currently do not reflect a large number of specialized sectors in the field of interior design. This is perhaps due to the newness of the field in the Kingdom and the rapid development and continued growth of the interior design sector every year (Al-Zahrani, 2016). Therefore, it is necessary to create ongoing external partnerships with the labour market and update the curriculum to match labour market needs (Hendy, 2018). It has been mentioned that there are deficiencies in the available information about the interior design specialization due to its newness, which has led to a misunderstanding of the speciality and a lack of clarity of vision (Alawad \& Bettaieb, 2016; Samak, 2010). There are specialized areas in the field of interior design that can lead to a professional path (Samak, 2010). In addition to specializations that are similar in their outcomes, such as interior architecture, interior design also comes into direct contact with different professions about which the interior designer must be knowledgeable and constantly informed (Alawad \& Bettaieb, 2016). Al-Zahrani recommended institutions open interior design departments and open a programme to fill the gap in the labour market (Al-Zahrani, 2016).

Interior design programmes have intellectual and applied value, as they defined as a complex system consisting of several chains represented by the designer, client, space, and design process (Alawad \& Bettaieb, 2016). It is a multifaceted profession that provides technical and creative solutions for indoor environments to enhance quality of life for the individual. Samak defined interior design as "the complete innovative solution to an interior space, as it includes conceptual planning, technical, and applied solutions to enhance and confirm the desired results" (Samak, 2010). In addition, it involves creating internal 
spaces and solving space problems to enable the performance of various activities based on user needs and the consideration of functional and aesthetic demands (Farran, 2019; Alawad \& Bettaieb, 2016). An interior designer must have a large amount of specialized knowledge and skills that allow him or her to follow the rapid development of modern techniques in materials, lighting and acoustics (Alawad \& Bettaieb, 2016) and address the needs and hopes of clients, which evolve based on development and globalization.

As academic programmes need a certain amount of time to develop their programmes, making it difficult for them to keep up with rapid change, studies that reveal the needs of the labour market are required to prepare graduates. Programme development is the responsibility of the academic department and involves creating a curriculum and syllabus that cover important topics and activities that enrich knowledge, develop skills and increase competencies. In addition, students should be motivated to develop themselves through, at the very least, elective courses that are aligned with modern trends in the labour market.

According to previous theory, the research problem is described by the following question: Are the outcomes of interior design programmes compatible with the needs of the labour market? The objectives of this study are to identify the knowledge and skills that students in interior design gain during their academic studies, to identify the similarities and differences between program curricula in the different regions of the Kingdom, to understand the needs of the labour market from the perspective of interior design programme graduates, and to study the limits of the KSA labour market with regard to interior design programmes. This study was carried out in 2019-2020.

This study is one of the first related to interior design, as previous studies were concerned with learning outcomes in general. The following benefits are expected from the results of this study:

- Helping the educators to develop academic programmes in universities considering the requirements of the labour market and including them in long-term study plans or short-term activities and topics.

- Helping students who are newly graduated or expected to graduate become familiar with the requirements of the labour market and develop their knowledge and skills through the appropriate selection of elective courses while contributing to increasing students' competencies in alignment with the needs of the labour market.

- Helping employers become acquainted with the outcomes of higher education institutions to contribute to choices that are consistent with their goals and provide necessary training to those who work for them.

Learning outcomes are the final result of the knowledge and skills gained during the learning process and are based on the student's profile and specialization. The Saudi labour market is the job opportunities available in the government and private sectors that are compatible with graduate specialities and with the knowledge and skills that were acquired during university study. 


\subsection{Previous Studies}

Badri (2017) studied challenges in the relationship between learning outcomes and the labour market for information sciences in the KSA by reviewing graduate statistics over ten years (2004-2014) and performing a content analysis of fourteen studies that explored the most important challenges in the relation between outcomes and the labour market in information science. Those challenges included a widening gap between the educational framework and the economic framework due to the weak partnership among educational institutions, governmental and private institutions, the lack of field training for students in external sectors, the absence of professional guidance, and weak academic guidance. The researcher also recommended a partnership between higher education and external sectors to ensure the quality of academic plans and training and graduate employment.

In another study carried out by Damanhori (2013), "Causes for Non-Adequate of Higher Education output the Requisites of the Saudi Labour Market", the researchers measured the attitudes of academics at the Faculty of Arts and Sciences. There were 218 participants and officials in human resources management in the private sector, and there were 270 participants. The study found that the most important reasons for the lack of alignment between higher education outcomes and the requirements of the labour market were an increase in the number of university enrolments and weak academic guidance in directing those admitted to the programmes aligned with what is required by the labour market. Additionally, the curricula did not align with the development needs of the labour market, there was a lack of practical experience among graduates, and the graduates had shortfalls in some skills, such as English language skills. The researcher recommended coordination between higher education institutions and external sectors to determine the needs of the labour market.

Al-Zahrani (2018) also examined the suitability of the outcomes of art education programmes with regard to the needs of the Saudi labour market according to Saudi Vision 2030. This study involved interviews with 7 experts from the education, design and museum sectors. A questionnaire was distributed to 117 graduates of the Department of Art Education. The study concluded that the educational outcomes were not compatible with the needs of the labour market except in three aspects: education, scientific research, and museums. The researcher recommended the establishment of a college for design and the establishment of specialized tracks to supply the labour market with graduates with specialized human resources skills and skills in various design specialities. Additional recommendations included coordination with community sectors to create future plans based on the needs of the labour market, communication with various organizations to train students and provide them with experience in how to deal with the labour market before graduation by studying the actual needs of the labour market and the creation and development of an approach based on those investigations. 
A study by Al-Otaibi (2007) analysed the suitability of higher education outcomes for the needs of the Saudi labour market. The study followed the descriptive analytical approach and study found that a relative weakness in applied scientific disciplines compared to theoretical specializations. The authors also pointed out that graduates must have specialized capabilities and skills that are appropriate to the labour market and that specialization is needed in order to fill the jobs available in the private sector. The study recommended promoting practical specialized skills that serve the labour market, such as English and computer skills, and creating partnership agreements with the private sector to develop curricula and transfer modern labour market trends to educational institutions so that the labour market does not have to adjust to the outcomes of higher education institutions.

A study carried out by Ahmed (2017) revealed the extent to which higher education programmes and curricula respond to the needs of the labour market in Algeria from the viewpoint of university students of both sexes. The study involved 230 students in specific disciplines, such as psychology, sociology, literature and foreign languages. The questionnaire contained four axes that included programme content, alignment of content with the labour market, competencies and skills acquired by students, and graduation projects, and the results show that the educational programs' response to the needs of the labour market was weak on the overall score for performance.

In Jordan, Ayrout (2012) conducted a study aimed at revealing the degree of compatibility between the majors and programmes offered by Princess Alia College and Amman University College and the requirements of the Jordanian labour market from students' point of view and demographic variables. A questionnaire was distributed to the students, and a number of responses were received (766). The questionnaire was divided into five areas: graduate's match with the labour market, guiding students towards the labour market, compatibility between information technology skills and the requirements of the labour market, and students' performance, cognitive skills, and attitude development. The study results showed that the degree of compatibility between the majors and programmes offered by Princess Alia College and Amman University College and the requirements of the Jordanian labour market was moderate according to students' perspectives (2.68). The researcher recommended effective partnerships with governmental and private community institutions, conducting future studies on the harmonization of the outputs of higher education institutions and the labour market, working to offer specializations compatible with the labour market, and holding training courses for students before graduation.

A study by Nicolescu \& Paun (2009), in Romania identified the quality of higher education services from the point of view of graduates and employers, as they are the main beneficiaries of higher education services. Many of the 2006 graduates from one college (School of Business and International Economics) from the Academy of Economic Studies responded, as well as a number of employers of graduates from the abovementioned institution. This resulted in a re- 
sponse rate of $91.1 \%$. In the two questionnaires, graduates and employers were asked about the skills and capabilities developed through higher education programmes and their compatibility with expectations and requirements. The study reported several results, including that graduates and employers have similar expectations of higher education institutions but to different degrees. The graduates emphasized acquiring knowledge, skills, and practical abilities, which they believed should be gained through their studies, such as the ability to absorb new knowledge, the ability to work in teams, and written and oral communication. Employers emphasized the moral and psychological characteristics of the individual when selecting employees, which are actually less related to skill acquisition through study. However, practical abilities are also important for employers and ranked second among the employer requirements, although the employers preferred that these be acquired through professional experience rather than undergraduate study.

Menon et al. (2018) studied graduate employment experiences and perceptions regarding the contribution of higher education to their careers and career prospects. Qualitative research was used to collect information from 58 university graduates in Greece and Cyprus. The results revealed that the graduates were generally satisfied with the quality of their education, but they pointed to many problems related to a difference between initial expectations and the reality of the labour market. The study results clarified the need for higher education institutions to review their study plans for compatibility with development and changes in the labour market to better prepare graduates. The participants also provided information about the skills and competencies gained through higher education and their use in the labour market, as well as between knowledge and competencies not based on knowledge acquired through higher education and the requirements of careers after graduation.

A study in Sweden by Lindberg (2010) examined the extent of judgement on the outcomes of a medical programme to prepare students to work as doctors. Personal interviews were conducted with 32 graduates and 123 professionals who had worked for a period of one to twenty-one years. Graduates were asked to assess the importance of each competency, their self-evaluation of their competence, and how these competencies are addressed during their medical training. The results indicated that there were deficiencies in the programme in preparing them satisfactorily. The study also clarified problem areas, finding that despite extensive practical training, medical education still faces some problems in the transition from education to employment.

It is clear that from previous studies that there are deficiencies in some programs to meet the requirements of the labour market as a result of several factors, including the shortage of partnership between educational institutions and the labour market, students training, academic guidance. To ensure rapid student engagement in the labour market, the previous studies suggested many recommendations, including the necessity of establishing effective partnerships with governmental and private community institutions, communicating with 
various organizations to train students, and conducting future studies on how to adapt higher education learning outcomes to labour market needs.

\section{Research Methodology}

This study used the descriptive analytical approach and reviewed 29 Saudi universities in all regions of KSA, and 19 programmes were listed. We analysed the study plans of academic programmes for interior design at public (11) and private (8) universities and designed two questionnaires for 60 graduates and 19 employers in fields of design and architecture who hire local interior designers.

\subsection{Academic Programmes}

Researchers selected 19 study plans to analyse. The criteria for selecting universities are summarized as follows:

- Diversity of universities from different regions of the Kingdom to understand the differences among programmes in the Kingdom.

- Diversity of public and private higher education institutions to understand differences in their outcomes.

- The bachelor's degree was chosen to ensure that the outcomes were compatible with the programmes.

- Flexibility in the name of the programme's interior design curriculum, as it is not an obstacle in the labour market.

- Acceptance of different certificate types, such as bachelor of science or arts, as this is not an obstacle on the labour market.

The purpose of analysing study plans in academic programmes was to identify the knowledge and skills that interior design students acquire during their academic studies and to identify the similarities and differences among the curricula in the same programme. Academic programmes were listed on official websites for the colleges/universities, and personal contact between the researchers and the academic departments identified other study plans. The courses were classified according to their explicit names or their content, if available, with researchers acknowledging that many of the courses develop other skills, such as in the interior design studio.

\subsection{Graduate Questionnaire}

The questionnaire was designed to collect the data necessary to identify the professional skills required for an interior designer in the labour market. The questionnaires were distributed to recent graduates according to the following criteria:

- Not exceeding five years for graduation.

- Graduating from different regions of the Kingdom.

The purpose of this questionnaire was to measure the compatibility of the outcomes of the interior design major in Saudi universities with the needs of the labour market from the point of view of the graduates, such as where they 
worked and what they controlled.

Alawad \& Bettaieb (2016) divided the design process and project management into seven states as follows:

The first stage is the beginning of the project, in which the general project framework is defined, the time period for the implementation of the project is determined, the approximate budget and material cost of the project are established, and a mechanism is established for how to communicate between the project parties and schedule the design process.

The second stage is programming, which involves visiting the site, surveying it, collecting data, setting an initial work plan to start implementing the project and obtaining the customer's approval.

The third stage is conceptualization, which involves developing the initial idea for the project, revising after presenting it to the customer and receiving approval.

The fourth stage is development of the concept, which involves final drawings being approved in preparation for transition to the implementation stage and the selection of materials and lighting and other elements for purchase, such as furniture and accessories. Additionally, the chosen colours and final finishes for the design are determined, and the designs for the ceilings and floors are finalized and approved. This entire stage is conducted using an organized presentation method and presented to the client in order to receive final approval to start implementation.

The fifth stage is design implementation, which is when everything that was agreed upon in the previous stages is implemented by issuing purchase orders, preparing construction drawings for the implementation stages, selecting contractors, setting a timetable related to implementation and issuing work orders.

The sixth stage is supervision of implementation, which involves construction being supervised and ascertaining the accuracy of the complete design during application while avoiding errors and ensuring the quality of the materials used; the extent of their conformity with what was agreed in advance as well as the quantities of the materials; and coordinating the work and making sure that it coincides with the implementation plan.

The seventh stage is post-implementation, which involves amending incoming errors, following up on the initial operation, terminating the contract, and handing over the final project.

\subsection{Employers Questionnaire}

A questionnaire was distributed to more than 100 employers who have offices related to interior design, and 41 answers were received. Offices that did not have graduates from the University of the Kingdom were excluded, and 19 employer responses were analysed. This questionnaire measures the extent to which higher education outcomes correspond to the needs of the labour market. Employer opinions regarding the following topics were elicited through the questionnaire: 
1) Personal, business and professional data.

2) New graduate skills in the field of interior design.

The same questionnaire was distributed to the graduates to determine the similarities and differences in opinions between graduates and employers.

\section{Results and Discussion}

The study plans have been analysed to identify the knowledge, skills and competencies that the student acquires during their studies to have a clear vision when analysing the results of the questionnaires for graduates and employers.

The researchers believe that development is a continuous process that starts from educational institutions through feedback from the labour market to ensure that students are engaged in the labour market and meet its needs.

\subsection{Academic Programmes Results}

This study analysed 19 study plans from different regions of the Kingdom as shown in Figure 1, and the proportions differ based on region size and whether the university is public or private. Through research into the universities, it was found that the Department of Interior Design is housed in colleges with different names, which may affect the programme in terms of policies it must adhere to even if the other programmes in the department are not related to design or architecture. This issue is especially relevant to materials related to college requirements and facilities that have no relationship to interior design or only serve interior designers indirectly, and these differences are illustrated in Figure 2.

Through the analysis, the study also found a difference among the study plans in terms of credit and contact hours, the number of years required for graduation, the proportion of core subjects, and elective subject materials and general materials as shown in Figure 3. These differences may affect students in terms of constructing a designer's profile, as there were different materials among colleges.

There was also a preparatory year in the first year of enrolment in the universities, and the programmes differed: some have a first year that is both specialized

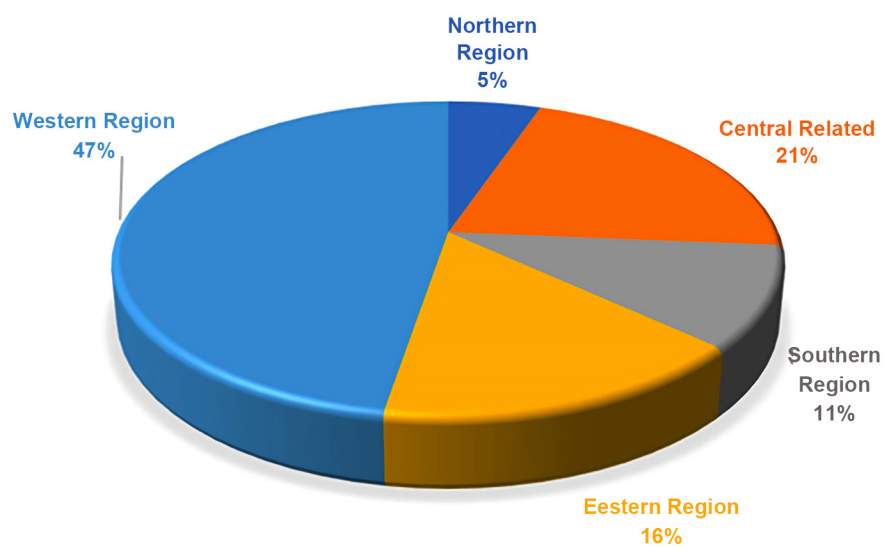

Figure 1. Regions of the Kingdom where the studied programmes are located. 


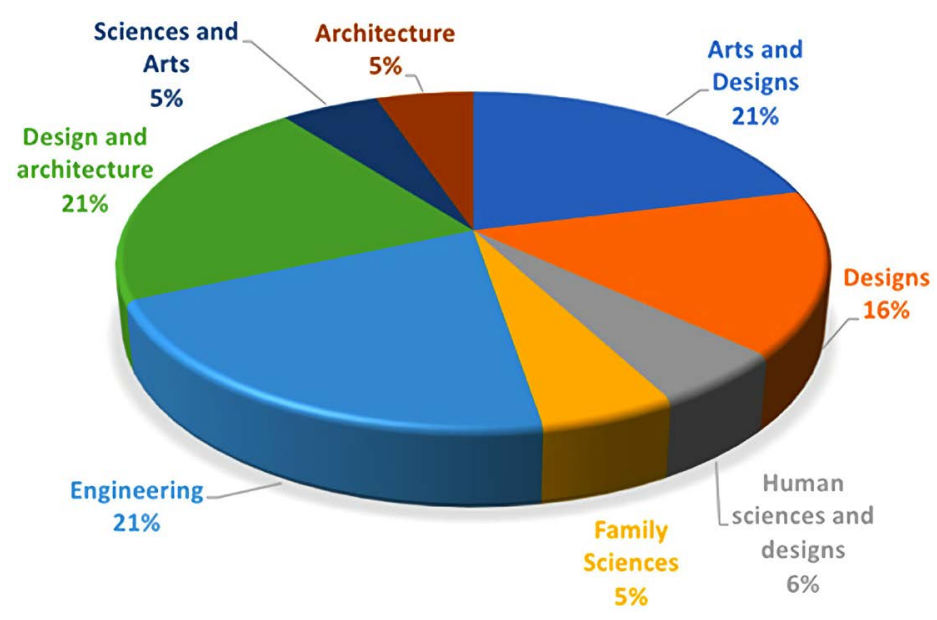

Figure 2. The colleges in which the interior design specialization is housed.

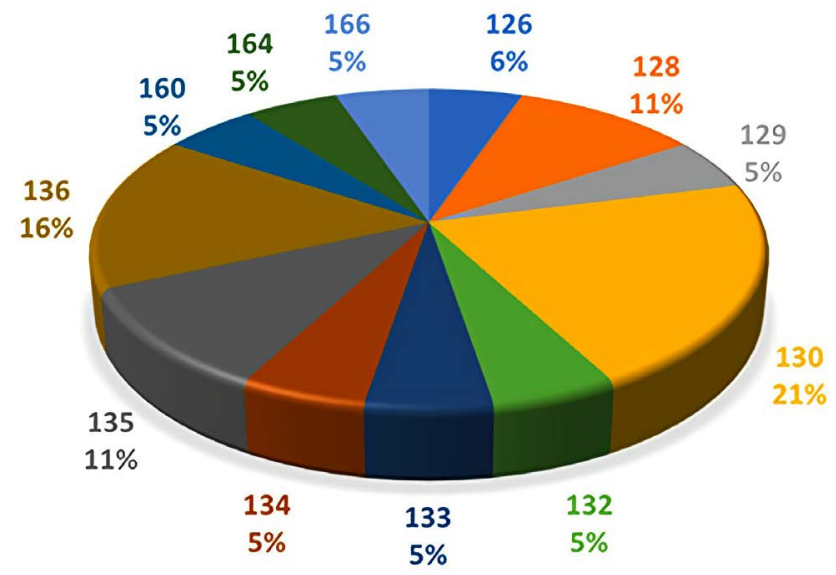

Figure 3. Differences in the number of hours required for the interior design programme.

and foundational, some colleges offer specialized subjects in the first year, and others offer general subjects, such as culture and writing skills and others, as Figure 4 shows.

Researchers found it difficult to search for study plans and communicated with some colleges personally, which affected the impression of the programme and led to an unclear image of the interior design programmes. Some colleges failed to update their websites, which is an interface with link between them and the external community, leading to misunderstandings about specialization and a lack of clarity among students wishing to join the programme (Alawad \& Bettaieb, 2016; Samak, 2010). It was also noted that interior design programmes in colleges allow only female students despite the community's need for the profession, which is consistent with other reports (Al-Zahrani, 2016).

During analysis of the study plans for each programme, it was found that some plans include each component at different ratios. Programmes are keen to start to teach students design elements and principles, theories and concepts, and manual drawing skills through the study of the principles of architectural and engineering drawing and creative and critical thinking skills at the level of 


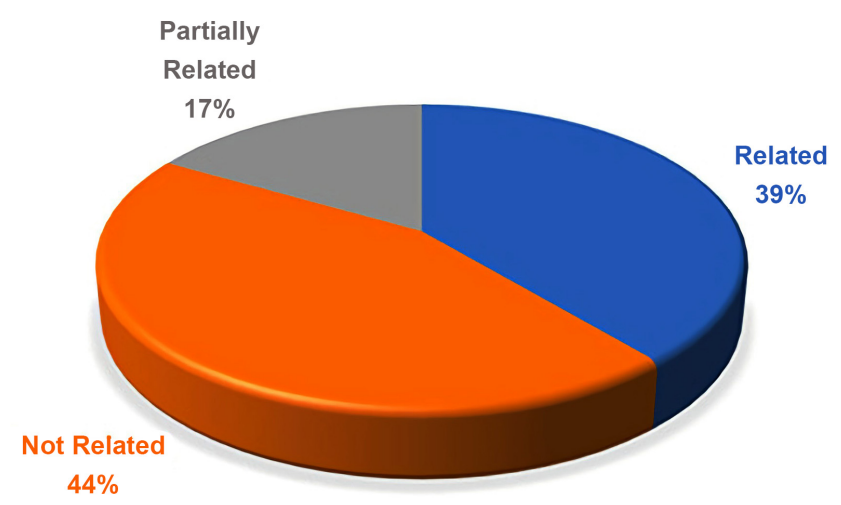

Figure 4. The different preparatory years for the major.

small spaces to suit the needs of clients. Students also study the foundations of raw materials and colour schemes and begin becoming acquainted with the design process. They start with a residential project with limited clients to unlimited clients, as the administrative, commercial, and even tourism fields require higher levels of knowledge and skills at advanced levels. Local identity and professional ethics are also emphasized. They also develop the ability to devise creative solutions to design problems with respect to national and international standards and guidelines for applying awareness of the relationship among cultural differences, social and political influences, limited resources, human behaviour and environments.

The interior design studio provides the physical and theoretical basis that enables students to apply what they learned in theoretical subjects and elective courses. There are also required subjects for each university and for each college, and here the role of academic guidance is to direct students to what suits them and support them, as the student can also take elective subjects from other colleges. It is possible to direct students to take subjects from, for example, the departments of law or marketing to support students' knowledge and skills through the study of subjects that are not included or lacking in the study plan.

It was also observed that the interior design programmes do not meet the needs of the market because some regions of the KSA do not have an interior design programme or have programmes that are limited to women. In addition, the image of interior design is not clear in some programmes due to lack of information available to society. This lack of information distorts the impression of interior design among students, parents, employers and even investors, and it does not conform to the requirements of academic accreditation in terms of clarity, transparency and advertising.

\subsection{Questionnaire Results}

There were 60 responses from graduates of interior design at Saudi universities. There were 19 responses from employers who have hired graduates of interior design programmes at Saudi universities, but half of that number were excluded due to the shortage of employees who were graduates of Saudi universities, 
which has been reported before (Al-Zahrani, 2016). There is a lack of competencies among Saudi workers in the field of interior design, especially with regard to the field's rapid development and increasing growth.

The questionnaire included several axes based on the research of Alawad \& Bettaieb (2016), which were used to divide the design process and project management into seven main stages. Table 1 shows the initial data, such as professional status, nature of the profession, and graduates general views of the programme, and Table 2 shows the location of the employers' offices.

It is clear from the graduates' answers that the number of employer is small for those participating in the questionnaire, which may be because the positions are filled by non-Saudi designers. The researchers excluded a number of questionnaires because there was no local designer working in the office. In addition, it is possible that this deficiency is because the graduates of interior design programmes are working as freelancers. It is worth noting that there is compatibility between the job description and the tasks entrusted to the graduate working in the interior design firm, which shows that the employer has knowledge of the job and tasks of the designer. It is clear from the previous table that approval for the extent of the programme's compatibility with the job market in the field of interior design is high (62.5\%).

Table 2 shows the percentage of employers and their office locations across the regions of the Kingdom. A number of respondents were excluded due to the lack of a Saudi designer working in their office, and the goal was to measure the learning outcomes of Saudi universities and their compatibility with the labour market. There was a lack of interior design programmes and design offices in the area (Participant-P/Graduate-G/Employee-E).

It is clear from Table 3 that interior design graduates have strong communication skills and can coordinate between the different project teams, with $55 \%$ of graduates and $47.4 \%$ of employers reporting agreement with the related statement. Graduates (46.7\%) and employers (47.4\%) both disagreed that graduates

Table 1. Shows the initial data.

Occupational status

\begin{tabular}{|c|c|c|c|}
\hline \\
\hline \multicolumn{2}{|c|}{ Employee } & \multicolumn{2}{|c|}{ Graduates } \\
\hline \multicolumn{2}{|c|}{15} & \multicolumn{2}{|c|}{45} \\
\hline \multicolumn{2}{|c|}{$25 \%$} & \multicolumn{2}{|c|}{$75 \%$} \\
\hline \multicolumn{4}{|c|}{ Job description compatible with duties } \\
\hline Strongly Disagree & Disagree & Strongly Agree & Agree \\
\hline $6.3 \%$ & $18.8 \%$ & $18.8 \%$ & $56.3 \%$ \\
\hline \multicolumn{4}{|c|}{$\begin{array}{l}\text { General opinion of programme graduates regarding programme } \\
\text { compatibility with the interior design job market }\end{array}$} \\
\hline Strongly Disagree & Disagree & Strongly Agree & Agree \\
\hline $6.3 \%$ & $25 \%$ & $6.3 \%$ & $62.5 \%$ \\
\hline
\end{tabular}


Table 2. Office locations.

\begin{tabular}{ccccc}
\hline \multicolumn{5}{c}{ Office Locations } \\
\hline South & North & Central & Eastern & Western \\
$5 \%$ & $0 \%$ & $35 \%$ & $30 \%$ & $30 \%$ \\
\hline
\end{tabular}

Table 3. Shows the beginning stage of the project.

\begin{tabular}{lccccc}
\hline \multicolumn{1}{c}{ The Question } & P & Agree & $\begin{array}{c}\text { Strongly } \\
\text { Agree }\end{array}$ & Disagree & $\begin{array}{c}\text { Strongly } \\
\text { Disagree }\end{array}$ \\
\hline $\begin{array}{l}\text { An interior design graduate can coordinate } \\
\text { the work of all project design teams }\end{array}$ & G & $55 \%$ & $10 \%$ & $31.7 \%$ & $3.3 \%$ \\
$\begin{array}{l}\text { An interior design graduate can estimate } \\
\text { the approximate cost for projects }\end{array}$ & G & $47.4 \%$ & $10.5 \%$ & $42,1 \%$ & $0 \%$ \\
$\begin{array}{l}\text { An interior design graduate can write } \\
\text { contracts }\end{array}$ & G & $36.8 \%$ & $0 \%$ & $47.4 \%$ & $15.8 \%$ \\
\hline
\end{tabular}

could estimate the approximate cost of projects. Forty-eight percent of graduates reported that they strongly disagreed that they had the ability to write contracts, and $72.8 \%$ of employers reported that they disagreed with this statement. It is clear that graduates have the ability to communicate with others, as this task is addressed in the basic studio during the study period, but the cost of the project as a whole may include several considerations that graduates are unable to estimate, resulting in an inability to write contracts that depend on those considerations. It is clear that there is agreement between the graduates and the employers on these skills.

The questionnaire responses revealed that some graduates were deficient in some skills, such as setting budgets and writing contracts, although the analyses showed that related courses are part of the study plan. The researchers believe that either the full number of hours in the study plan were not completed or that the courses were elective, and the students were not guided with regard to the priority of important courses. These results are consistent with a study by $\mathrm{Da}-$ manhori (2013), which found that regardless of the type of skill, graduates have some deficiencies in skills that the labour market needs.

It is clear from Table 4 that the graduates of interior design programmes can inspect the project site and take measurements and initial drawings, with $50 \%$ of graduates and $47.4 \%$ of employers reporting that they agree with the relevant statement. Data collection was also a skill that $48.3 \%$ of graduates and $47.4 \%$ of employers agreed the graduates had. Graduates (56.7\%) and employers (52.6\%) agreed that graduates could develop an initial plan, and this statement had the highest percentage of "agree" responses; it was clear that the employers agreed with the graduates with regard to the answers. Agreement was reported from approximately half the participants who filled out the questionnaire.

Table 5 shows that the graduates of interior design programmes can develop 
Table 4. Shows the programming stage.

\begin{tabular}{lccccc}
\hline \multicolumn{1}{c}{ The Question } & P & Agree & $\begin{array}{c}\text { Strongly } \\
\text { Agree }\end{array}$ & Disagree & $\begin{array}{c}\text { Strongly } \\
\text { Disagree }\end{array}$ \\
\hline $\begin{array}{l}\text { An interior design graduate can preview the } \\
\text { site, photograph it, take measurements and }\end{array}$ & G & $50 \%$ & $28.3 \%$ & $16.7 \%$ & $5 \%$ \\
draw a sketch & E & $47.4 \%$ & $21.1 \%$ & $31.6 \%$ & $0 \%$ \\
$\begin{array}{l}\text { An interior design graduate can collect } \\
\text { project-related data }\end{array}$ & G & $48.3 \%$ & $40 \%$ & $11.7 \%$ & $0 \%$ \\
$\begin{array}{l}\text { An interior design graduate can develop an } \\
\text { initial plan to start implementing the }\end{array}$ & G & $47.4 \%$ & $21.1 \%$ & $31.6 \%$ & $0 \%$ \\
project & E & $52.6 \%$ & $10.5 \%$ & $36.8 \%$ & $0 \%$ \\
\hline
\end{tabular}

Table 5. Shows the conceptualization stage.

\begin{tabular}{|c|c|c|c|c|c|}
\hline The Question & $\mathbf{P}$ & Agree & $\begin{array}{c}\text { Strongly } \\
\text { Agree }\end{array}$ & Disagree & $\begin{array}{l}\text { Strongly } \\
\text { Disagree }\end{array}$ \\
\hline \multirow{2}{*}{$\begin{array}{l}\text { An interior design graduate can develop } \\
\text { an initial concept and create sketches }\end{array}$} & G & $53.3 \%$ & $45 \%$ & $1.7 \%$ & $0 \%$ \\
\hline & $\mathrm{E}$ & $68.4 \%$ & $31.6 \%$ & $0 \%$ & $0 \%$ \\
\hline \multirow{2}{*}{$\begin{array}{l}\text { An interior design graduate can come up } \\
\text { with a variety of design ideas }\end{array}$} & G & $51.3 \%$ & $43.7 \%$ & $5 \%$ & $0 \%$ \\
\hline & $\mathrm{E}$ & $68.4 \%$ & $21.1 \%$ & $10.5 \%$ & $0 \%$ \\
\hline \multirow{2}{*}{$\begin{array}{l}\text { An interior design graduate can } \\
\text { interview clients }\end{array}$} & G & $48.3 \%$ & $40 \%$ & $11.7 \%$ & $0 \%$ \\
\hline & $\mathrm{E}$ & $63.2 \%$ & $26.3 \%$ & $5.3 \%$ & $5.3 \%$ \\
\hline \multirow{2}{*}{$\begin{array}{l}\text { An interior design graduate can market } \\
\text { his or her ideas to persuade the client }\end{array}$} & G & $58.3 \%$ & $31.7 \%$ & $10 \%$ & $0 \%$ \\
\hline & $\mathrm{E}$ & $68.4 \%$ & $15.8 \%$ & $15.8 \%$ & $0 \%$ \\
\hline \multirow{2}{*}{$\begin{array}{l}\text { An interior design graduate can identify } \\
\text { modern technologies }\end{array}$} & G & $61.7 \%$ & $18.3 \%$ & $20 \%$ & $0 \%$ \\
\hline & $\mathrm{E}$ & $63.2 \%$ & $5.3 \%$ & $31.6 \%$ & $0 \%$ \\
\hline
\end{tabular}

an initial concept and design ideas and then revise them after submitting them to the client and receiving approval. This skill had the greatest agreement, with $53.3 \%$ of graduates agreeing and $45 \%$ strongly agreeing and $68.4 \%$ of employers agreeing and $31.6 \%$ strongly agreeing. Graduates agreed (51.3\%) or strongly agreed (43.7\%) that they could come up with a variety of design ideas, and employers agreed $(68.4 \%)$ or strongly agreed $(21.1 \%)$ that graduates had this skill. Both graduates (48.3\%) and employers (63.2\%) agreed that graduates could interview customers, and $58.3 \%$ of graduates and $68.4 \%$ of employers agreed that graduates could market their ideas to persuade the client.

The highest percentage of agreement was found for the statement that an interior design graduate can identify modern technologies: $61.7 \%$ of graduates agreed, and $63.2 \%$ of employers agreed. It is clear from this table that the percentage of respondents reporting strongly agree or agree were highest for the statement that graduates had strengths in this stage related to communication skills and persuasion skills and skills for translating ideas into sketches because of the diversity of ideas and continuous access to modern technologies. They have knowledge of what is new, which has been shown before (Alawad \& Bet- 
taieb, 2016), and of the importance of informing the client and knowing what is new in the design world in terms of technology and materials.

The results in Table 6 shows that graduates have the ability to choose materials, colours, lighting, and finishes in accordance with the design and that are available in the market, with $56.7 \%$ of graduates and $68.4 \%$ of employers reporting they agree with this statement. Reviewing the client's decisions and discussing and trying to persuade the client to adopt what is suitable for the project received a high percentage of agree responses from graduates (56.7\%) and employers (52.6\%). It is clear from this table that graduates can choose items for the project, meaning that they have good decision-making skills, and it is clear from the previous tables that they have negotiation and persuasion skills.

The results of Table 7 show that graduates of interior design programmes can calculate the quantities necessary for design work, with $41.7 \%$ of graduates and $63.2 \%$ of employers reporting they agree with the related statement. However, graduates tended to disagree $(51.7 \%)$ and employers tended to agree $(57.9 \%)$ that graduates could estimate the timetable for completing projects. The level of agreement regarding graduates' ability to make decisions and issue purchase orders was $48.3 \%$ among graduates, whereas employers felt otherwise and did not agree (47.4\%). These results make sense because if a graduate is self-employed, it is his or her responsibility to make purchasing decisions, while if the graduate work in an office, there are policies under which only the owner of the office has the power to make purchase decisions.

There was agreement between the graduates and employers that the graduates of interior design programmes cannot choose the contractors/workers to accomplish the requirements of the projects, with $60 \%$ of graduates and $52.6 \%$ of

Table 6. Shows the developing the visualization stage.

\begin{tabular}{|c|c|c|c|c|c|}
\hline The Question & $\mathbf{P}$ & Agree & $\begin{array}{l}\text { Strongly } \\
\text { Agree }\end{array}$ & Disagree & $\begin{array}{l}\text { Strongly } \\
\text { Disagree }\end{array}$ \\
\hline $\begin{array}{l}\text { An interior design graduate can choose } \\
\text { materials that are available in the market }\end{array}$ & G & $56.7 \%$ & $28.3 \%$ & $13.3 \%$ & $1.7 \%$ \\
\hline and correspond to the design & $\mathrm{E}$ & $68.4 \%$ & $10.5 \%$ & $21.1 \%$ & $0 \%$ \\
\hline $\begin{array}{l}\text { An interior design graduate can choose } \\
\text { colours that are available in the market }\end{array}$ & G & $56.7 \%$ & $28.3 \%$ & $13.3 \%$ & $1.7 \%$ \\
\hline and correspond to the design & $\mathrm{E}$ & $68.4 \%$ & $10.5 \%$ & $21.1 \%$ & $0 \%$ \\
\hline A graduate of interior design can choose & G & $56.7 \%$ & $28.3 \%$ & $13.3 \%$ & $1.7 \%$ \\
\hline $\begin{array}{l}\text { lighting that is available in the market } \\
\text { and aligned line with the design }\end{array}$ & $\mathrm{E}$ & $68.4 \%$ & $10.5 \%$ & $21.1 \%$ & $0 \%$ \\
\hline $\begin{array}{l}\text { An interior design graduate can choose } \\
\text { finishes that are available in the market }\end{array}$ & G & $56.7 \%$ & $28.3 \%$ & $13.3 \%$ & $1.7 \%$ \\
\hline and correspond to the design & $\mathrm{E}$ & $68.4 \%$ & $10.5 \%$ & $21.1 \%$ & $0 \%$ \\
\hline $\begin{array}{l}\text { An interior design graduate can review } \\
\text { decisions with the client and discuss and } \\
\text { try to persuade him or her regarding } \\
\text { what is in the interest of the project }\end{array}$ & G & $52.6 \%$ & $26.3 \%$ & $15.8 \%$ & $5.3 \%$ \\
\hline
\end{tabular}


Table 7. Shows the implementation stage.

\begin{tabular}{|c|c|c|c|c|c|}
\hline The Question & $\mathbf{P}$ & Agree & $\begin{array}{l}\text { Strongly } \\
\text { Agree }\end{array}$ & Disagree & $\begin{array}{l}\text { Strongly } \\
\text { Disagree }\end{array}$ \\
\hline $\begin{array}{l}\text { An interior design graduate can calculate } \\
\text { the quantities needed for the design }\end{array}$ & G & $41.7 \%$ & $15 \%$ & $33.3 \%$ & $10 \%$ \\
\hline work. & $\mathrm{E}$ & $63.2 \%$ & $5.3 \%$ & $26.3 \%$ & $5.3 \%$ \\
\hline \multirow{2}{*}{$\begin{array}{l}\text { An interior design graduate can estimate } \\
\text { the project completion schedule }\end{array}$} & $\mathrm{G}$ & $31.7 \%$ & $13.3 \%$ & $51.7 \%$ & $3.3 \%$ \\
\hline & $\mathrm{E}$ & $57.9 \%$ & $0 \%$ & $31.6 \%$ & $10.5 \%$ \\
\hline \multirow{2}{*}{$\begin{array}{l}\text { An interior design graduate can make } \\
\text { decisions and make purchase orders }\end{array}$} & G & $48.3 \%$ & $16.7 \%$ & $35 \%$ & $0 \%$ \\
\hline & $\mathrm{E}$ & $31.6 \%$ & $15.8 \%$ & $47.4 \%$ & $5.3 \%$ \\
\hline $\begin{array}{l}\text { An interior design graduate can choose } \\
\text { contractors/workers to fulfil project }\end{array}$ & G & $30 \%$ & $5 \%$ & $60 \%$ & $5 \%$ \\
\hline requirements & $\mathrm{E}$ & $26.3 \%$ & $5.3 \%$ & $52.6 \%$ & $15.8 \%$ \\
\hline \multirow{2}{*}{$\begin{array}{l}\text { An interior design graduate can work in a } \\
\text { multifunctional design team }\end{array}$} & G & $55 \%$ & $40 \%$ & $5 \%$ & $0 \%$ \\
\hline & $\mathrm{E}$ & $73.7 \%$ & $26.3 \%$ & $0 \%$ & $0 \%$ \\
\hline \multirow{2}{*}{$\begin{array}{l}\text { An interior design graduate can manage } \\
\text { executive projects }\end{array}$} & G & $36.7 \%$ & $11.7 \%$ & $45 \%$ & $6.7 \%$ \\
\hline & $\mathrm{E}$ & $31.6 \%$ & $5.3 \%$ & $52.6 \%$ & $10.5 \%$ \\
\hline
\end{tabular}

employers reporting they disagreed with this statement. The highest percentage of agreement among graduates related to their ability to work in a multifunctional design team (55\%), and $73.7 \%$ of employers agreed with this. These results are compatible with those in the previous tables about the graduates' strengths in communication skills. Regarding graduates' ability to manage executive projects, $45 \%$ of graduates disagreed, and only $36.7 \%$ agreed. In addition, $52.6 \%$ of employers disagreed and only $31.6 \%$ agreed with this statement. The convergence of opinions regarding the implementation of a project may be due to the quality and size of the project.

The results of Table 8 show that a similar percentage of agree responses were reported by graduates with regard to being flexible with changes to the project, avoiding errors in work through supervision, adjusting tables according to project circumstances, and supervising the implementation of projects. On the other hand, the employers reported a similar level of agreement regarding graduates' ability to be flexible with project changes, avoid errors and supervise implementation (47.4\%) and graduates' ability to adjust tables (46.4\%).

Finally, these results clarify that if there is disagreement in the previous schedule, the graduate will not able to apply the abovementioned skills related to project management, but it is clear in this schedule that they are able to supervise and match written and agreed-upon work with real work, which indicates an ability to follow-up and supervise. With regarding graduates' ability to write reports, $48.3 \%$ of graduates strongly disagreed, and from $72.8 \%$ of employers disagreed.

The results show that the graduates have good knowledge and skills in the field of interior design, with some shortfalls in project management skills that are required in the labour market, such as calculating budgets, writing work 
Table 8. Shows the supervision of implementation and after implementation stage.

\begin{tabular}{|c|c|c|c|c|c|}
\hline The Question & $\mathbf{P}$ & Agree & $\begin{array}{l}\text { Strongly } \\
\text { Agree }\end{array}$ & Disagree & $\begin{array}{l}\text { Strongly } \\
\text { Disagree }\end{array}$ \\
\hline \multirow{2}{*}{$\begin{array}{l}\text { An interior design graduate can flexibly } \\
\text { handle project situations }\end{array}$} & G & $48.3 \%$ & $18.3 \%$ & $30 \%$ & $3.3 \%$ \\
\hline & $\mathrm{E}$ & $47.4 \%$ & $5.3 \%$ & $42.1 \%$ & $5.3 \%$ \\
\hline \multirow{2}{*}{$\begin{array}{l}\text { An interior design graduate can avoid } \\
\text { mistakes through supervision }\end{array}$} & $\mathrm{G}$ & $48.3 \%$ & $18.3 \%$ & $30 \%$ & $3.3 \%$ \\
\hline & $\mathrm{E}$ & $47.4 \%$ & $5.3 \%$ & $42.1 \%$ & $5.3 \%$ \\
\hline \multirow{2}{*}{$\begin{array}{l}\text { An interior design graduate can adjust } \\
\text { tables according to project circumstances }\end{array}$} & $\mathrm{G}$ & $48.3 \%$ & $18.3 \%$ & $30 \%$ & $3.3 \%$ \\
\hline & $\mathrm{E}$ & $46.4 \%$ & $6.3 \%$ & $42.1 \%$ & $5.3 \%$ \\
\hline \multirow{2}{*}{$\begin{array}{l}\text { An interior design graduate can supervise } \\
\text { project implementation }\end{array}$} & G & $48.3 \%$ & $13.3 \%$ & $35 \%$ & $3.3 \%$ \\
\hline & $\mathrm{E}$ & $47.4 \%$ & $10.5 \%$ & $36.8 \%$ & $5.3 \%$ \\
\hline \multirow{2}{*}{$\begin{array}{l}\text { An interior design graduate can write } \\
\text { reports }\end{array}$} & G & $35 \%$ & $3.3 \%$ & $13.3 \%$ & $48.3 \%$ \\
\hline & $\mathrm{E}$ & $9.1 \%$ & $9.1 \%$ & $72.8 \%$ & $9.1 \%$ \\
\hline
\end{tabular}

contract timetables, and writing reports. On the other hand, it is clear that the graduates have good communication, negotiation, persuasion and decision-making skills.

Although programmes do not update their curricula until they have graduated a cohort of students and measured outcomes, it is possible that there is an obligation to provide academic guidance to aid students in choosing optional and general courses and various activities to support the acquisition of required skills. This may coincide with previous reports (Badri, 2017) finding that weak academic guidance affects the learning and ability of students to engage in the labour market. In this study, there was no weakness in English language skills or computer skills, as shown previously (Al-Otaibi, 2007; Al-Damanhouri, 2013) because the interior designers were skilled in the English language. It is a requirement to update designer information because it is one of the basic skills. Computer skills are one of the simplest skills, and there are even specialized programmes in design, such as AutoCAD, and 3D Max, that the designer relies on to complete work.

\section{Conclusion}

It is clear from this study that specialization is concentrated in some regions and is rare in other regions. The differences among interior design programmes are noted at several points, and these include the colleges in which the programmes are housed, which have different required hours and number of plans, and the proportion of core, elective and general courses. Additionally, there is a preparatory year in the first year of joining the programme, and the programmes differ, with some having a specialized first year that is foundational and some colleges offering some subjects in the first year and others offering general subjects that researchers believe will affect the students' knowledge and skills. Researchers encountered difficulty studying academic plans because some of them have 
not been updated and are difficult to access, rendering it difficult to develop a mental image of the program. In addition, this shortage of information does not conform to academic accreditation standards in terms of clarity and advertising.

It was also noted that the interior design programme in some colleges is only for female students, despite the community's need for this profession. It was revealed through this research that the number of employees at interior design companies is limited compared to the number of graduates. In addition, there was limited compatibility between the job description and the tasks assigned to the employees at the interior design company, which indicates that the employer has knowledge of interior design jobs and tasks. Finally, it is clear that the graduates are generally satisfied with the skills and knowledge gained during their studies.

It is clear from the graduates' and employers' responses to all the questions that students have specialized skills but that they are deficient in some special skills related to project management that are required in the labour market and if they work as freelancers. Graduates have strong competencies in communication skills and working in a team, as well as in negotiation, persuasion and decision-making skills.

The researchers recommend that study plans be updated to align with the requirements of the labour market. Additionally, more academic guidance is needed during their studies to guide students to elective courses and activities such as workshops that meet the needs of the labour market. Joint work between the labour market and the academic department will help ensure programmes are updated to reflect new trends in the labour market.

Future studies should address the reasons behind the small number of Saudi employees in design and architecture offices, the impact general courses in the first year on learning outcomes and becoming an interior designer, the importance of the role of the designer in the development of the Kingdom, and the importance of creating accurate paths in interior design.

\section{Conflicts of Interest}

The authors declare no conflicts of interest regarding the publication of this paper.

\section{References}

Ahmed, Z. (2017). University Programs and Their Responsiveness to the Needs of the Labour Market. Human Development Journal, 7, 159-189.

Alawad, A., \& Bettaieb, D. (2016). Interior Design, Professional Practice and Competency Requirements. International Design Journal, 6, 101-108.

Al-Otaibi, M. (2007). Analysis of the Compatibility of Higher Education Outcomes with the Labour Market Requirements in Saudi Arabia. Educational Journal-Kuwait University, 5, 7-31.

Al-Zahrani, M. (2016). The Role of Art Education Departments and Interior Design Departments in Saudi Universities in the Interior Design Sector, in the Kingdom of Saudi 
Arabia. International Educational Specialization Journal, Jordanian Society of Psychology, 5, 411-427. https://doi.org/10.12816/0035709

Al-Zahrani, M. (2018). The Suitability of the Outcomes of the King Saud University Art Education Program with the Needs of the Saudi Labour Market According to Vision 2030. Journal of Educational Sciences, 30, 427-451.

Ayrout, M. (2012). The Degree of the Compatibility of Majors and Programs Provided by Princess Alia College and Amman University College for the Requirements of the Jordanian Labor Market as Perceived by Students Themselves. Muta for Research and Studies, Humanities and Social Sciences Series, 27, 179-228.

Badri, A. (2017). The Demands of Saudi Labour Market for Information Technology Specializations and the Challenges Facing Higher Education: A Content Analysis. Taibah University Journal: Arts and Humanities, 6, 735-768.

Dagher, A., Tarawneh, A., \& Amin, M. (2016). The Degree of Harmonization of Jordanian Higher Education Outputs to Labour Market Need. Studies, Educational Sciences, 43, 2033-2049.

Damanhori, H. (2013). Causes for Non-Adequate of Higher Education Output the Requisites of the Saudi Labour Market. King Abdulaziz University Journal, Economics and Administration, 27, 169-225. https://doi.org/10.4197/Eco.27-1.4

Dar Al-Hekma (2020). http://www.dah.edu.sa/en/about/Pages/History.aspx

Farran, H. (2019). The Importance of Influence of Interior Design in Promoting the Arab Cultural Identity of Internal Space. Journal of Architecture, Arts and Humanistic Science, 4, 599-616.

Hendy, A. (2018). The Interior Design and Furniture Program of the Faculty of Applied Arts in Damietta between Reality and the Hoped. Journal of Architecture, Arts and Humanistic Science, 11, 112-126. https://doi.org/10.12816/0046881

Lindberg, O. (2010). “The Next Step”-Alumni Students' Views on Their Preparation for Their First Position as a Physician. Medical Education Online, 15, 4884. https://doi.org/10.3402/meo.v15i0.4884

Menon, M. E., Argyropoulou, E., \& Stylianou, A. (2018). Managing the Link between Higher Education and the Labour Market: Perceptions of Graduates in Greece and Cyprus. Tertiary Education and Management, 24, 298-310. https://doi.org/10.1080/13583883.2018.1444195

Nicolescu, L., \& Paun, C. (2009). Relating Higher Education with the Labour Market: Graduates' Expectations and Employers' Requirements. Tertiary Education and Management, 15, 17-33. https://doi.org/10.1080/13583880802700024

Samak, M. (2010). Specialist Concept \& Profession Challenges between Theory and Practice: A Study on Interior Design Specialist. Journal of Fine Arts-Alexandria University, 3, 51-66. 